\title{
Apoptotic effects of non-edible parts of Punica granatum on human multiple myeloma cells
}

\author{
Yağmur Kiraz $^{1,2}$ • Vidushi S. Neergheen-Bhujun ${ }^{3}$ - Nawraj Rummun ${ }^{3}$ Yusuf Baran ${ }^{1,2}$
}

Received: 4 June 2015 / Accepted: 20 August 2015 / Published online: 29 August 2015

(C) International Society of Oncology and BioMarkers (ISOBM) 2015

\begin{abstract}
Multiple myeloma is of great concern since existing therapies are unable to cure this clinical condition. Alternative therapeutic approaches are mandatory, and the use of plant extracts is considered interesting. Punica granatum and its derived products were suggested as potential anticancer agents due to the presence of bioactive compounds. Thus, polypenolic-rich extracts of the non-edible parts of $P$. granatum were investigated for their antiproliferative and apoptotic effects on U266 multiple myeloma cells. We demonstrated that there were dose-dependent decreases in the proliferation of U266 cells in response to P. granatum extracts. Also, exposure to the extracts triggered apoptosis with significant increases in loss of mitochondrial membrane potential in U266 cells exposed to the leaves and stem extracts, while the flower extract resulted in slight increases in loss of MMP. These results were confirmed by Annexin- $V$ analysis. These results documented the cytotoxic and apoptotic effects of $P$. granatum extracts on human U266 multiple myeloma cells via disruption of mitochondrial membrane potential and increasing cell cycle arrest. The data suggest that the extracts can be envisaged in cancer chemoprevention and call for further exploration into the potential application of these plant parts.
\end{abstract}

Yağmur Kiraz and Vidushi S. Neergheen-Bhujun contributed equally to this work.

Yusuf Baran

ybaran@gmail.com

1 Department of Molecular Biology and Genetics, Izmir Institute of Technology, Urla 35430 Izmir, Turkey

2 Department of Molecular Biology and Genetics, Faculty of Life and Natural Sciences, Abdullah Gul University, Kayseri, Turkey

3 Department of Health Sciences, Faculty of Science and ANDI Centre of Excellence for Biomedical and Biomaterials Research, University of Mauritius, Reduit, Moka, Mauritius
Keywords Apoptosis · Cytotoxicity · Multiple myeloma · Pomegranate

\section{Introduction}

Cancer is a multifactoral disease, with a consequence of the unusual mechanisms of genetic, metabolic or biochemical factors, which basically spoil the controlled proliferation and/or apoptosis mechanism of the cells [1]. The unlimited ability of proliferation, the developed resistance against apoptotic signals, the capability of invasion, metastasis and angiogenesis, abnormal activity of energy metabolism and the defence against immune attack are the hallmarks of cancer [2, 3]. Each of these characteristic features of cancer cells is used as targets for different therapies. In addition, tumour cells usually acquire the ability to evade death by inactivating cell death pathways that normally function to eliminate damaged and harmful cells, a feature that often entails the development of chemotherapeutic resistance encountered during treatment.

An interesting strategy for targeting the cancer cells includes the use of chemicals, dietary biofactors, phytochemicals and even whole plant extracts to thwart the progress of cancers by halting/reversing tumor promotion/progression [4-6]. Previously, the anti-carcinogenetic properties of phytochemicals such as resveratrol, gingerol, caffeic acid phenyl ester or genistein were established in many different studies. [7]. Also, since the plant extracts include various types of metabolite that each of them can target different pathways, it creates a synergistic response in the cells, which makes the plant material more preferable for anti-cancer studies. However, the success of the evaluation of any anticancer agents depends critically on the interaction of basic, preclinical and clinical research in a cooperated network. 
Punica granatum L., also known as pomegranate, belonging Punicaceae family, has been documented to confer multiple health benefits in ethnomedicine and in multiple folklore medicinal system, including that of Mauritius [8-12]. It is known as an anti-bacterial, antidiabetic, anti-hypertensive and most importantly anticarcinogenic substance [8]. These types of metabological effects of $P$. granatum resulted from its secondary metabolite ingredients, especially polyphenolic composide, which is found at the high level in the plant [13-16]. Pomegranate has edible and non-edible parts that include different amounts of phytophenolic substances which have been studied very commonly $[8,17,18]$.

Pomegranate extract exhibits anticancer activity via inhibition of cell growth and survival on the human breast cancer (MCF-7) line in both time- and dose-dependent manner [19]. Pomegranate-derived ellagitannins showed in vitro anti-proliferative and anti-aromatase activity in breast cancer cells [13], while pomegranate juice consumption revealed a significant prolongation of prostatespecific antigen doubling time, in both an initial phase II clinical trial in patient with prostate cancer [20] and a randomized phase II study [21]. Raw pomegranate peel extract offers selective cytotoxic activity against promyelocytic (HL60) cell lines and immune-stimulatory effect in peripheral blood mononuclear cells [22]. Pomegranate juice extract polyphenols exhibited antileukemic activity by inducing apoptosis and inhibiting cellular proliferation by inducing $\mathrm{S}$ phase arrest in leukemia cell lines [16, 23].

The evaluation of pomegranate non-edible part extracts in altering the hallmarks of cancer cells is of interest to the scientific community as these parts could be promoted for use. Nevertheless, understanding the mechanisms of action of these extracts is particularly important. Thus, this study aimed at investigating the cytotoxic and apoptotic effects of non-edible parts of the Mauritian cultivar of pomegranate on U266 cells, with the view of promoting their utilisation in functional health and chemoprevention. U266 cells were chosen by considering their well characterization and convenient culture conditions. In this context, we evaluated the apoptotic effects of $P$. granatum leaves, flowers and stem extracts on U266 multiple myeloma cells by detection of cell proliferation, together with measuring mitochondrial membrane potential, and these results were confirmed by apoptotic assays. Cytostatic effects of $P$. granatum extracts (leaves, flowers and stem) were established by cell cycle analysis. Also, considering the lack of literature knowledge on the anticancer effects of $P$. granatum extracts on human multiple myeloma cells, this study represents a pioneer research in this area.

\section{Materials and methods}

\section{Plant materials}

Pomegranate plant and fruit parts were collected from a domesticated plant growing in a backyard in the Pamplemousses district of Mauritius Island. The plant parts were collected during the month of September 2011 and authenticated by the herbarium of Mauritius Sugar Industry Research Institute, Réduit. P. granatum leaves, stems, flowers and fruits were collected from the same plant. The latter were air-dried, and the samples were homogenised to a fine powder prior to extraction.

\section{Preparation of extracts}

The leaves, stems, flowers and fruit materials of P. granatum were extracted thrice with $70 \%$ methanol $(1: 3, w / v)$ and allowed to macerate each time at $4{ }^{\circ} \mathrm{C}$ for $24 \mathrm{~h}$ as described in Rummun et al. [24]. The filtrates were pooled together and concentrated in vacuo at $37^{\circ} \mathrm{C}$. The concentrated aqueous extract was partitioned in dichloromethane to remove fats and chlorophyll, and the aqueous phase was then collected and lyophilized. The lyophilized powders, thereof derived, were dissolved in deionized water and in $100 \%$ methanol to a concentration of $1 \mathrm{~g}$ of air-dried mass to $5 \mathrm{~mL}$ for the subsequent tests.

\section{Cell lines and culture conditions}

Human multiple myeloma U266 cells were obtained from American Type Culture Collection (ATCC TIB-196) and cultured in RPMI 1640 growth medium containing $10 \%$ fetal bovine serum and $1 \%$ penicillin-streptomycin at $37^{\circ} \mathrm{C}$ in $5 \%$ $\mathrm{CO}_{2}$.

\section{Measurement of cell proliferation by MTT assay}

Cytotoxic effects of P. granatum leaves, flowers and stem extracts on U266 cells were determined by MTT proliferation assay after 48 and $72 \mathrm{~h}$ of incubation with increasing concentration of the extracts. Initially, $1 \times 10^{4}$ cells in $100 \mu \mathrm{l}$ of medium were seeded in 96-well plates and 1-, 10-, 50-, $100 \mu \mathrm{g} / \mathrm{ml}$ of $P$. granatum flower extract, 1-, 10-, 50-, 100-, $500 \mu \mathrm{g} / \mathrm{ml}$ of $P$. granatum stem and leaves extracts were applied. Also, as the control group, cells were treated with no extracts but only culture media; then, they were incubated at $37{ }^{\circ} \mathrm{C}$ in $5 \% \mathrm{CO}_{2}$ for 48 and $72 \mathrm{~h}$. After the incubation period, $20 \mu \mathrm{l}$ of MTT was added and incubated for three more hours. Afterwards, the plates were centrifuged at $1800 \mathrm{rpm}$ for $10 \mathrm{~min}$, and supernatants were removed. MTT crystals were dissolved in $150 \mu \mathrm{l}$ of DMSO per well. Plates were shaken for $10 \mathrm{~min}$ at $150 \mathrm{rpm}$ for homogenisation. Finally, the plates were read at $570 \mathrm{~nm}$ 
wavelengths by fluorescence Elisa reader (Thermo Varioscan Spectrum, Finland), and $\mathrm{IC}_{50}$ values were calculated by the cell proliferation plots [25].

\section{Determination of the changes in mitochondrial membrane potential}

The loss of mitochondrial membrane potential (MMP) in U266 cells exposed to $1-, 10-, 50-$ and $100 \mu \mathrm{g} / \mathrm{ml}$ of $P$. granatum flower extract and 1, 10, 50, 100 and $500 \mu \mathrm{g} / \mathrm{ml}$ of P. granatum stem and leaves extracts was determined by JC-1 Mitochondrial Membrane Potential Detection Kit (Cell Technology, USA). As we did in MTT test, for the control group, cells were treated with no extracts but only culture media. The kit utilises JC-1, a unique cationic dye that signals the loss of MMP. In apoptotic cells, MMP collapses and JC-1 dye remains in the cytoplasm as a monomer, which stains green under fluorescent light, whereas JC-1 passes and accumulates into the mitochondria and stains red in non-apoptotic cells. Initially, $1 \times 10^{6}$ cells in $2 \mathrm{ml}$ of medium were seeded in six-well plates, and the cells were exposed to 1-, 10-, 50- and $100 \mu \mathrm{g} / \mathrm{ml}$ of $P$. granatum flower extract and $1,10,50,100$ and $500 \mu \mathrm{g} / \mathrm{ml}$ of $P$. granatum stem and leaves extracts for 48 and $72 \mathrm{~h}$. Then, the cells were collected by centrifugation at $400 \mathrm{~g}$ for $10 \mathrm{~min}$ and pellets were homogenized by addition of $300 \mu \mathrm{l}$ medium; $30 \mu \mathrm{l}$ of JC- 1 dye was added onto the cells and incubated at $37{ }^{\circ} \mathrm{C}$ in $5 \% \mathrm{CO}_{2}$ for $30 \mathrm{~min}$. After incubation, they were centrifuged again at $400 \mathrm{~g}$ for $10 \mathrm{~min}$, supernatants were removed and pellets were homogenized by addition of $200 \mu \mathrm{l}$ JC-1 assay buffer. An additional $320 \mu \mathrm{l}$ of the assay buffer was added onto each sample and homogenized. Then, $100 \mu \mathrm{l}$ from each of them was transferred into a 96-well plate as triplicates. In non-apoptotic cells, red form of aggregates has absorption/emission maxima of 560/595 nm, while in apoptotic cells the monomeric green form has absorption/emission maxima of $485 / 535 \mathrm{~nm}$. The plate was read under these wavelengths by fluorescence Elisa reader (Thermo Varioscan Spectrum, Finland). The changes in MMP were determined by green/red values calculated for each concentration and for control groups as well [26].

\section{Analysis of apoptotic cells by Annexin-V-FITC/PI double staining}

Annexin-V/PI double staining was performed to determine the apoptotic effects of $P$. granatum extracts on U266 cells, and the percentage of apoptotic cell population was determined by flow cytometry. Annexin- $\mathrm{V}$ test is assessed based on determining an early marker of apoptosis, which is the translocation of phosphatidylserine from the inner membrane to the outer cell membrane. Briefly, $1 \times 10^{6}$ cells in $2 \mathrm{ml}$ medium were seeded in six-well plates, and they were treated with $1-, 10-, 50-$ and $100 \mu \mathrm{g} / \mathrm{ml}$ of $P$. granatum flower extracts and $1-, 10-, 50-, 100-, 500 \mu \mathrm{g} / \mathrm{ml}$ of P.granatum stem and leaves extracts for 48 and $72 \mathrm{~h}$, and for the control group, cells were treated with no extracts but only culture media. The cells were then washed twice with cold PBS, and pellets were resuspended in $1 \mathrm{ml}$ of $1 \mathrm{X}$ binding buffer. Then, $100 \mu \mathrm{l}$ of this mixture was transferred into glass tubes, and $5 \mu 1$ of Annexin-V-FITC $(50 \mu \mathrm{g} / \mathrm{ml})$ and $5 \mu \mathrm{l}$ of propidium iodide (PI, $100 \mu \mathrm{g} / \mathrm{ml}$ ) were added into the tubes. The samples were vortexed gently and incubated in the dark for $15 \mathrm{~min}$ at room temperature. Afterward, $400 \mu \mathrm{l}$ of $1 \mathrm{X}$ binding buffer was added to each sample and then analysed by flow cytometry (BD Facscanto flow cytometry, Belgium) within $1 \mathrm{~h} \mathrm{[26].}$

\section{Cell cycle analysis}

Amounts of dsDNA were determined by using propidium iodide (PI), a DNA-binding dye, by using flow cytometry (BD Facscanto flow cytometry, Belgium). The amounts of fragmented DNA in the cells can be determined by the data obtained and analysed from the flow cytometry. Initially, $1 \times 10^{6}$ cells in $2 \mathrm{ml}$ of medium were seeded in six-well plates, and they were treated with 1-, 10-, 50- and $100 \mu \mathrm{g} / \mathrm{ml}$ of $P$. granatum flower extracts and 1-, 10-, 50-, 100-, $500 \mu \mathrm{g} / \mathrm{ml}$ of $P$. granatum stem and leaves extracts for $72 \mathrm{~h}$. Likely to previous apoptotic tests, for the control group, cells were treated with no extracts but only culture media. After the incubation period, the cells were centrifuged at $400 \mathrm{~g}$ for $10 \mathrm{~min}$. Then, the pellets were resuspended in $1 \mathrm{ml}$ of cold PBS, and the samples were kept on ice during the follow-up steps. Then, $4 \mathrm{ml}$ of cold ethanol was added onto the cells while they were vortexed gently. All the samples were fixed at $-20{ }^{\circ} \mathrm{C}$ for at least $24 \mathrm{~h}$. The cells were then centrifuged at $400 \mathrm{~g}$ for $10 \mathrm{~min}$ again, and the pellet was homogenized with $1 \mathrm{ml}$ of cold PBS. Afterwards, cell pellets were resuspended in $1 \mathrm{ml}$ PBS containing $0.1 \%$ triton X-100. Then, $100 \mu \mathrm{l}$ of RNase A was added, and the cells were incubated at $37^{\circ} \mathrm{C}$ for $30 \mathrm{~min}$. Finally, $100 \mu \mathrm{l}$ of PI was added, and the cells were incubated at room temperature for 15 min before analysing by flow cytometry.

Statistical analyses Statistical significance was determined by using one-way analysis of variance (ANOVA) for MTT analyses and two-way ANOVA for JC-1, Annexin-V and cell cycle analysis. Differences between groups were considered as significant at a $P$ value of $<0.05$. Statistical analyses were performed with GraphPad Prism 6.0 (GraphPad Software, Inc., San Diego, CA, USA).

\section{Results}

\section{P. granatum extracts inhibited proliferation on U266 cells}

Cytotoxic effects of $P$. granatum leaves, flowers and stem extracts were determined by MTT proliferation assay after 
48 and $72 \mathrm{~h}$ of incubation with increasing concentration of the extracts. The calculated $\mathrm{IC}_{50}$ values of extracts for 48 and $72 \mathrm{~h}$ were 286 and $267 \mu \mathrm{g} / \mathrm{ml}$, respectively for $P$. granatum leaves, 41 and $25 \mu \mathrm{g} / \mathrm{ml}$ for $P$. granatum flowers, respectively, and 305 and $302 \mu \mathrm{g} / \mathrm{ml}$ for $P$. granatum stem extracts, respectively $(p<0.05)$ (Fig. 1a, b).

\section{P. granatum leaves, flowers and stem extracts showed apoptotic effect on $\mathrm{U} 266$ cells in a dose-dependent manner}

Annexin-V/PI double staining was performed to determine the apoptotic effects of $P$. granatum extracts, and the percentage of apoptotic cell population was determined by flow cytometry. Annexin-V analysis revealed that there were 13-, 17 and 19fold increases in apoptotic cell population of U266 exposed to 50,100 , and $500 \mu \mathrm{g} / \mathrm{ml}$ leaves extract for $72 \mathrm{~h}$, respectively, while 8-, 13-, and 15-fold increases in apoptotic cell population of U266 exposed to the same doses for $48 \mathrm{~h}$ (Fig. 2a, d). There were 1.8- and 1.6-fold increases in apoptotic cells exposed to 50 and $100 \mu \mathrm{g} / \mathrm{ml}$ flower extracts for $48 \mathrm{~h}$, while it was fourand 3.53-fold for $72 \mathrm{~h}$, respectively (Fig. 2b, e). Ten- and 16fold increases in apoptotic cell population were determined in U266 cells exposed to 100 and $500 \mu \mathrm{g} / \mathrm{ml} \mathrm{stem} \mathrm{extract} \mathrm{for} 48 \mathrm{~h}$, respectively, while 18- and 27-fold increase in apoptotic cell population was detected for $72 \mathrm{~h}$ of incubation as compared to control cells $(p<0.05)$ (Fig. 2c, f).
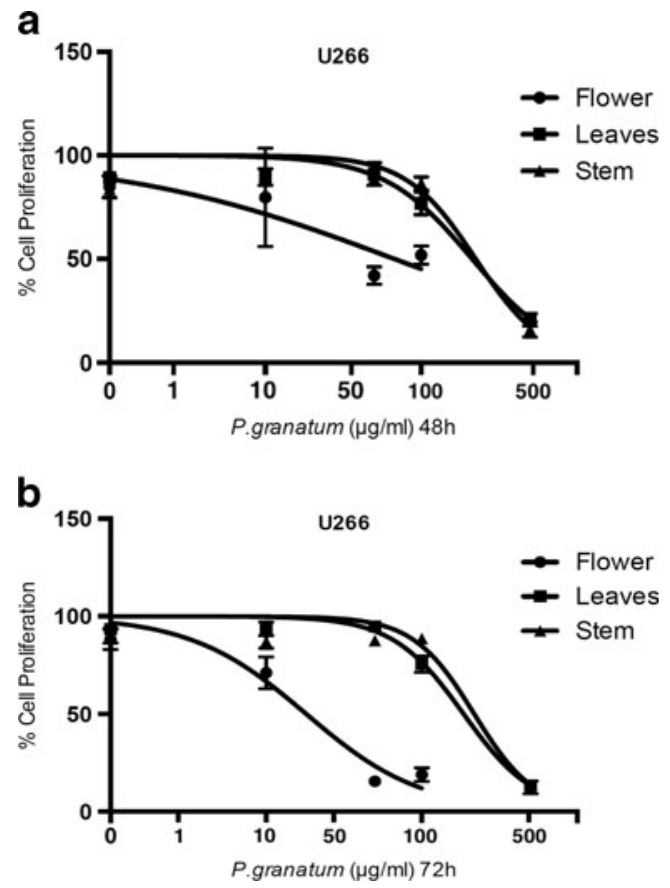

Fig. 1 Cytotoxic effects of $P$. granatum flower, leaves and stem extracts on U266 cells for 48 (a) and $72 \mathrm{~h}$ (b). IC50 value was determined from the cell proliferation plots. The error bars represent the standard deviations. Statistical significance was determined by using one-way ANOVA; $p<0.05$ was considered as significant
$P$. granatum leaves, flowers and stem extracts decreased MMP in U266 cells in a dose-dependent manner

In order to confirm the data obtained by the Annexin test, we determined the loss of mitochondrial membrane potential in
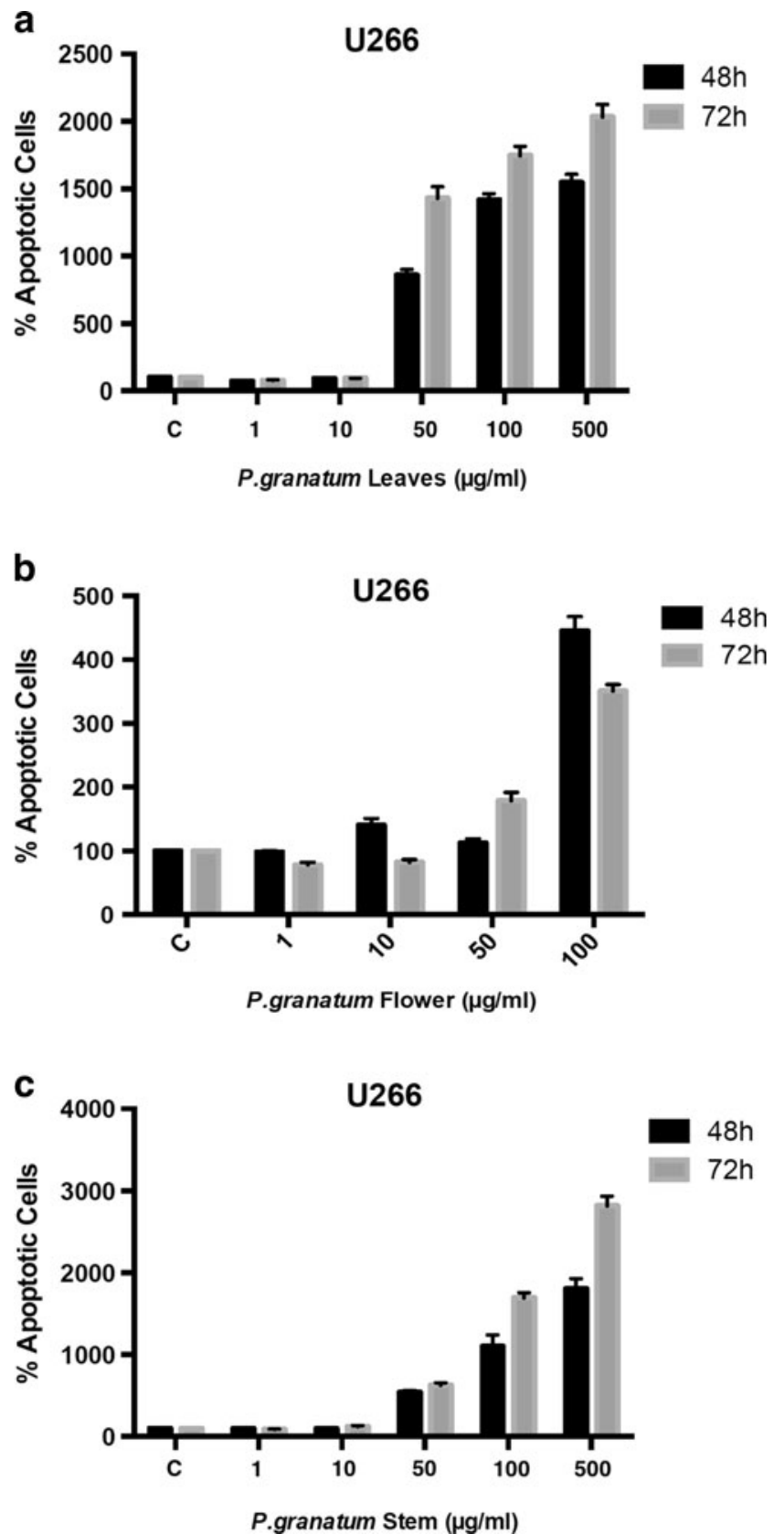

Fig. 2 Evaluation of apoptotic U266 cells exposed by $P$. granatum extracts. a Apoptotic cells that induced by $P$. granatum leaves extract and $P$. granatum flower and stem extracts, respectively $(\mathbf{b}, \mathbf{c})$. Flow cytometry results are shown in $\mathbf{d}$, e and $\mathbf{f}$, respectively. Cells in the lower right quadrant indicate Annexin-positive/PI-negative, meaning early apoptotic cells, while the cells in the upper right quadrant indicate Annexin-positive/PI-positive, late apoptotic cells. The error bars represent the standard deviations. Statistical significance was determined by using two-way ANOVA; $p<0.05$ was considered as significant 
d

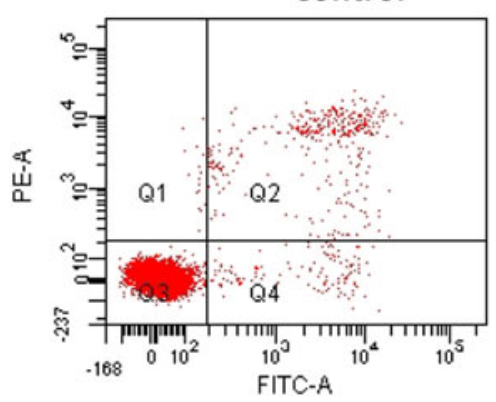

$50 \mu \mathrm{g} / \mathrm{ml}$

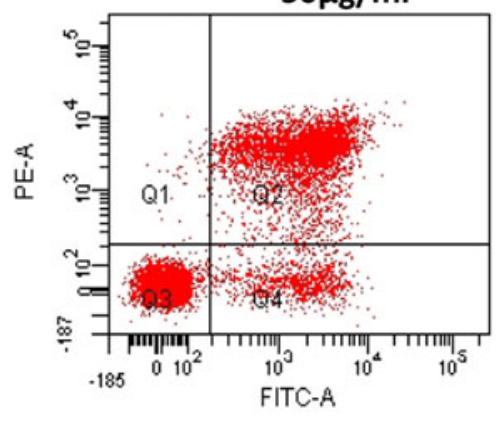

Control

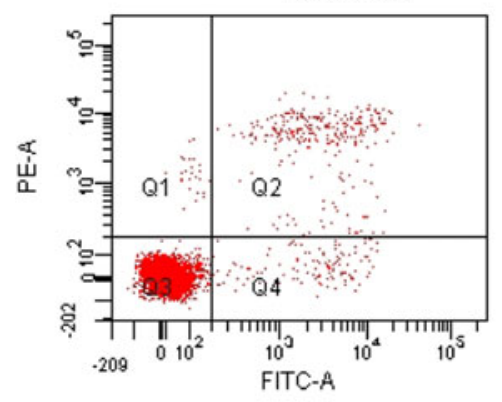

$50 \mu \mathrm{g} / \mathrm{ml}$

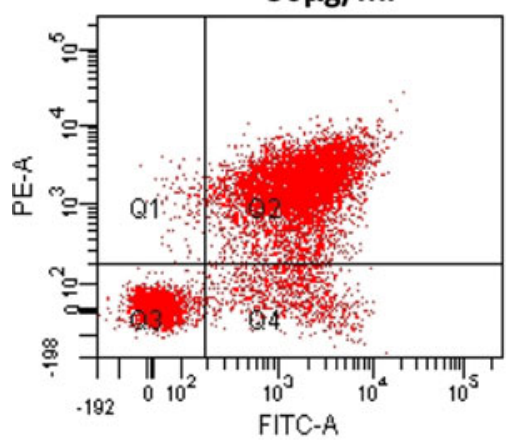

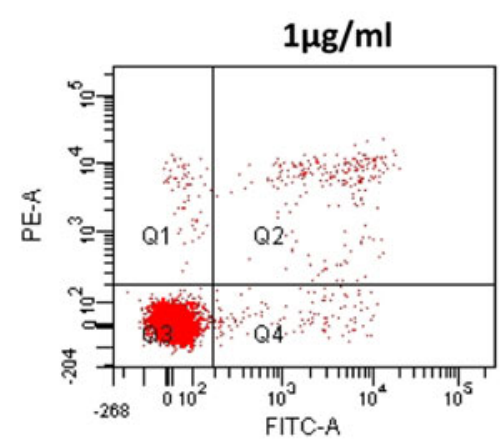

$100 \mu \mathrm{g} / \mathrm{ml}$

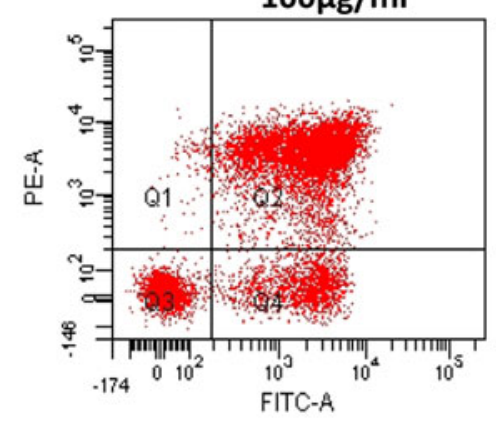

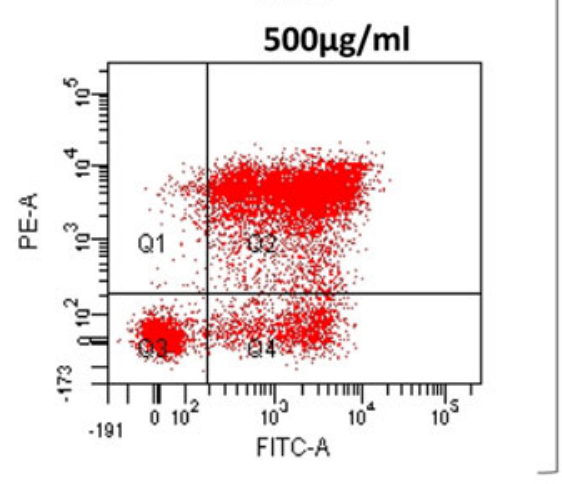

$48 \mathrm{~h}$
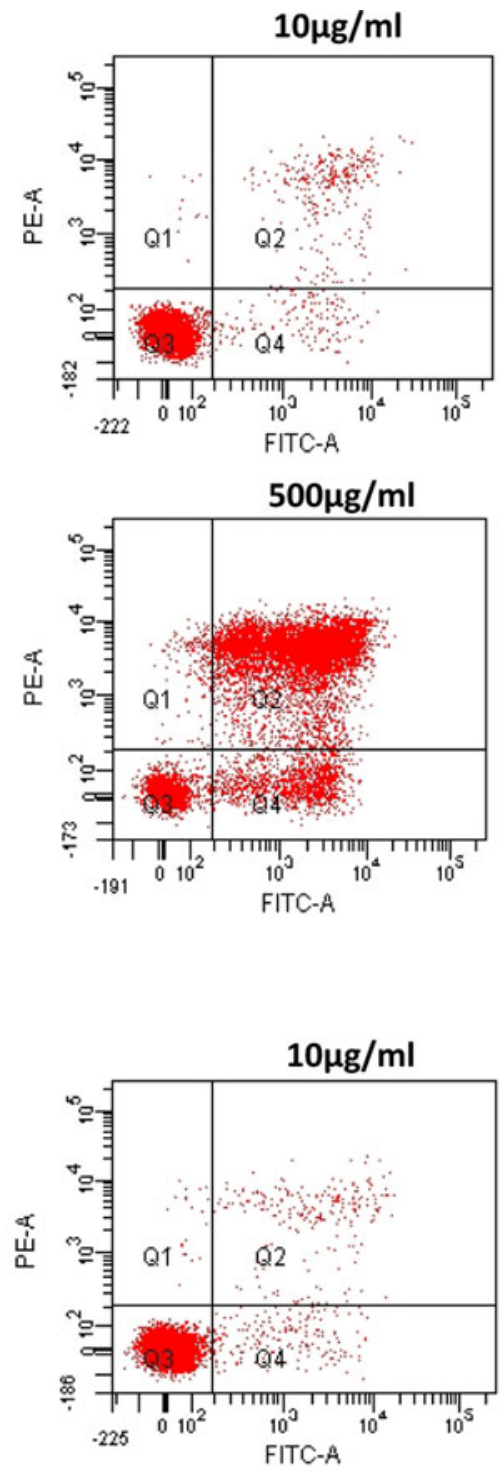

$72 \mathrm{~h}$

Fig. 2 (continued)

U266 cells exposed to increased concentrations of P. granatum $(p<0.05)$. There were 7.3- and 67.3-fold increases in loss of MMP in response to 250 and $500 \mu \mathrm{g} / \mathrm{ml}$ concentration of $P$. granatum leaves extract for $48 \mathrm{~h}$ and
70.3- and 226.4-fold increases in loss of MMP in response to the same concentrations for $72 \mathrm{~h}$, respectively (Fig. 3a). There were 1.69- and 3.76-fold increases in response to $50 \mu \mathrm{g} / \mathrm{ml}$ P. granatum flower extracts for 48 or $72 \mathrm{~h}$, 

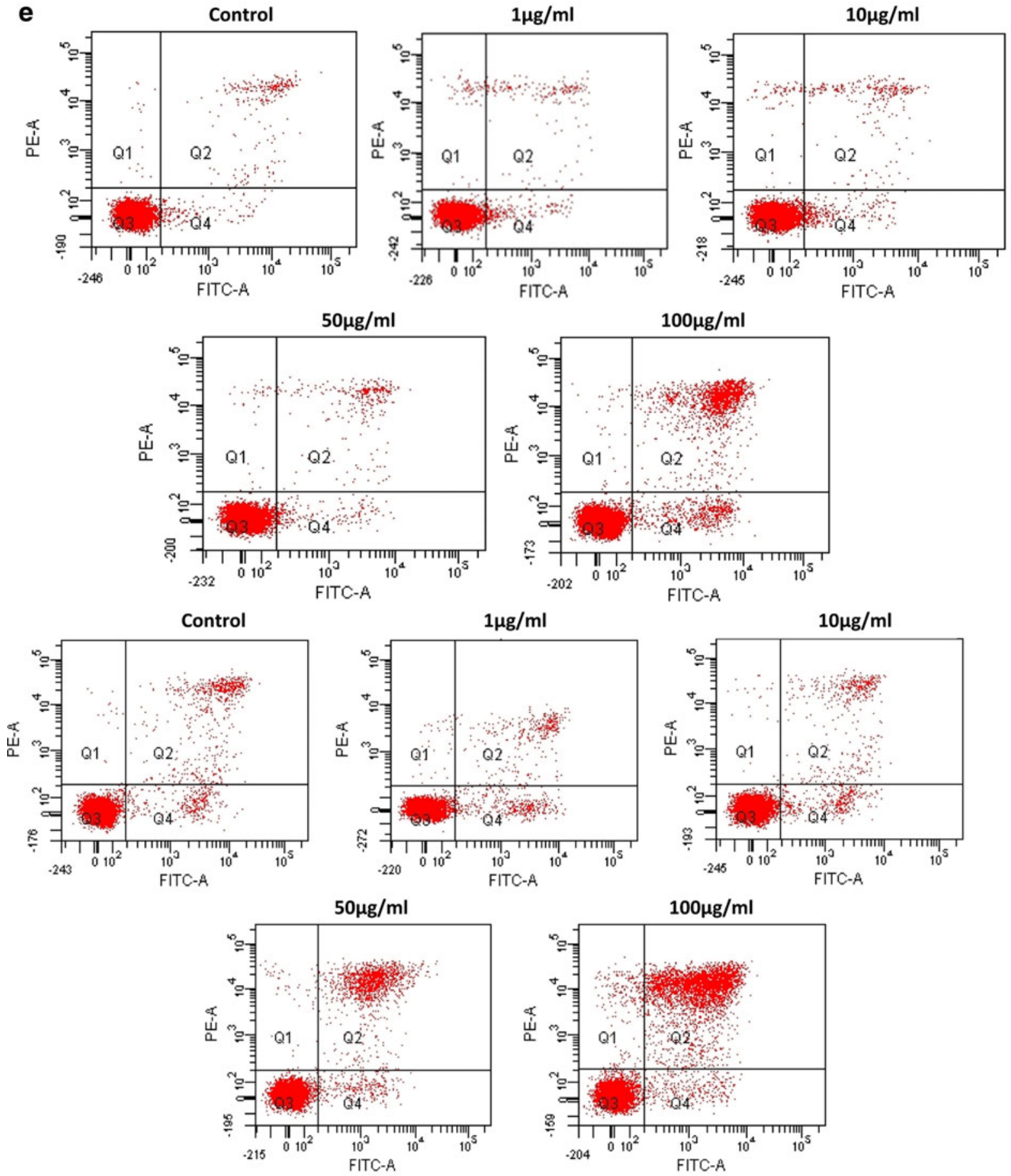

Fig. 2 (continued)

respectively, while $100 \mu \mathrm{g} / \mathrm{ml}$ P.granatum flower extracts application increased loss of MMP for 2.29- or 4.57-fold after 48 or $72 \mathrm{~h}$, respectively (Fig. 3b). On the other hand, $P$. granatum stem extract showed 1.66- and 2.52- or 1.37- and 2.45- fold increases in loss of MMP in response to 250 and $500 \mu \mathrm{g} / \mathrm{ml}$ concentrations for 48 or $72 \mathrm{~h}$, respectively (Fig. 3c).

\section{P. granatum leaves, flowers and stem extracts caused cell cycle arrest in $\mathrm{G} 2 / \mathrm{M}$ and $\mathrm{S}$ phases}

We determined the cytostatic effects of $P$. granatum extracts on MM cells. The leaves extracts increased the percentage of U266 cells in G2/M phase in a dose-dependent manner. In the untreated control group, there was $43 \%$ of population in G2/ 

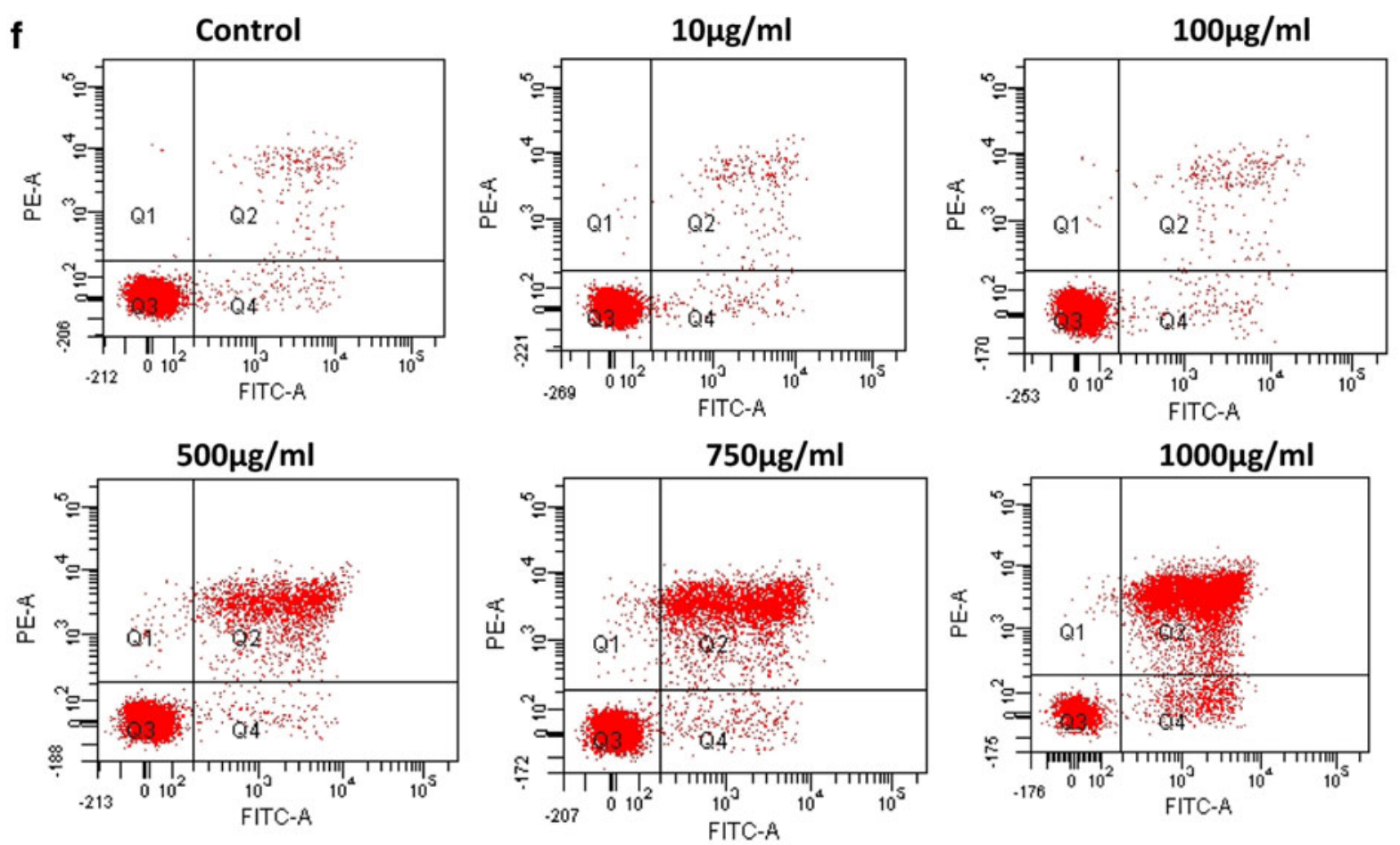

$48 \mathrm{~h}$
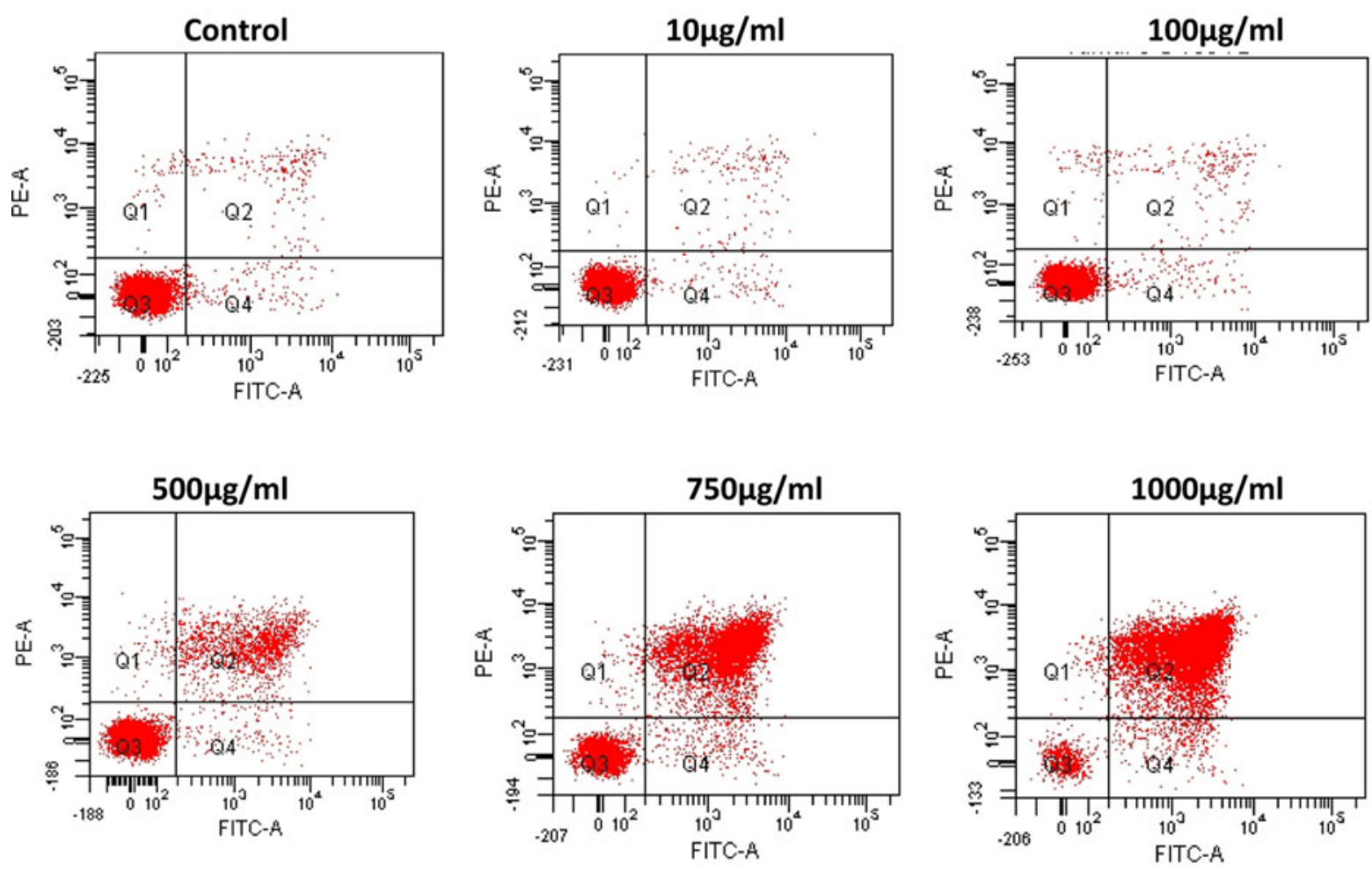

72h

Fig. 2 (continued)

M phase, while exposure to $250 \mu \mathrm{g} / \mathrm{ml}$ leaves extract arrested $59 \%$ of cells in G2/M phase. There was no differences in the $\mathrm{S}$ phase for the different concentrations used (Fig. 4a, d).
P. granatum flower extract increased U266 cell population in both $\mathrm{G} 2 / \mathrm{M}$ phase and $\mathrm{S}$ phase in a dose-dependent manner (Fig. $4 \mathrm{~b}, \mathrm{e}$ ). In the untreated control group, there was $53 \%$ of 

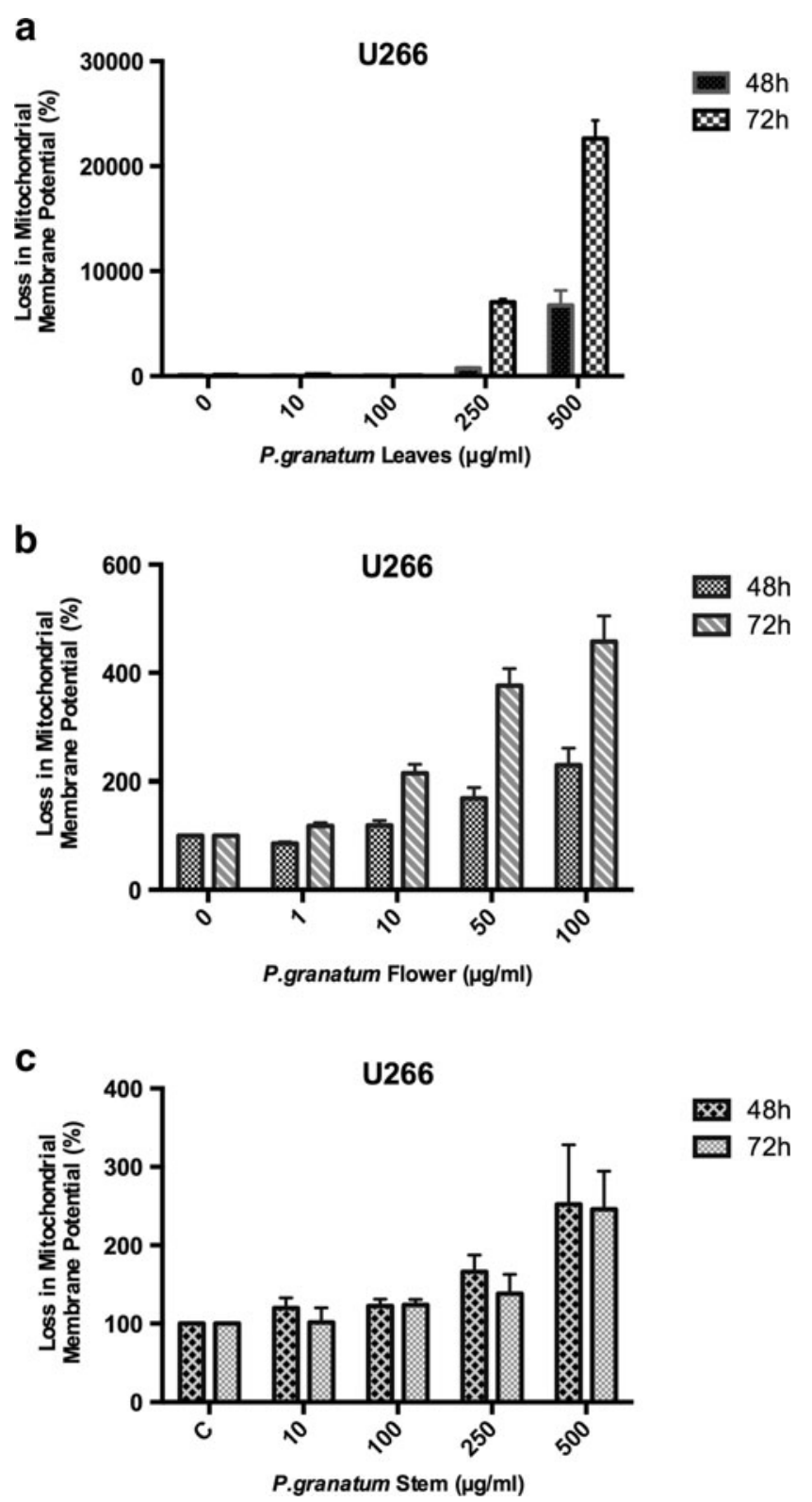

Fig 3 Changes in mitochondrial membrane potential in response to increasing concentration of $P$. granatum leaves (a), flower (b) and stem (c) extracts. The error bars represent the standard deviations. Statistical significance was determined by using two-way ANOVA; $p<0.05$ was considered as significant

population in $\mathrm{G} 2 / \mathrm{M}$ phase, while exposure to $100 \mu \mathrm{g} / \mathrm{ml}$ flower extract arrested $62 \%$ of cells in $\mathrm{G} 2 / \mathrm{M}$ phase. On the other hand, there was $1.7 \%$ of cell population in $\mathrm{S}$ in untreated control group, while exposure to $100 \mu \mathrm{g} / \mathrm{ml}$ flower extract arrested $8.6 \%$ of cells in $\mathrm{S}$ phase. Also, there were increases in the population of U266 cells in $\mathrm{G} 2 / \mathrm{M}$ phases, but not any substantial difference for $\mathrm{S}$ phases, and decreases in G0/G1 cell population in response to an increasing concentration of $P$. granatum stem extract (Fig. 4c, f). In the untreated control group, there was $43.8 \%$ of population in $\mathrm{G} 2 / \mathrm{M}$ phase, while exposure to $750 \mu \mathrm{g} / \mathrm{ml}$ stem extract arrested $61.7 \%$ of cells in $\mathrm{G} 2 / \mathrm{M}$ phase.

\section{Discussion}

Multiple myeloma is a systemic malignancy of pathologic plasma cells that results in the accumulation of the cancerous cells in the bones and bone marrow. Current clinical therapies for
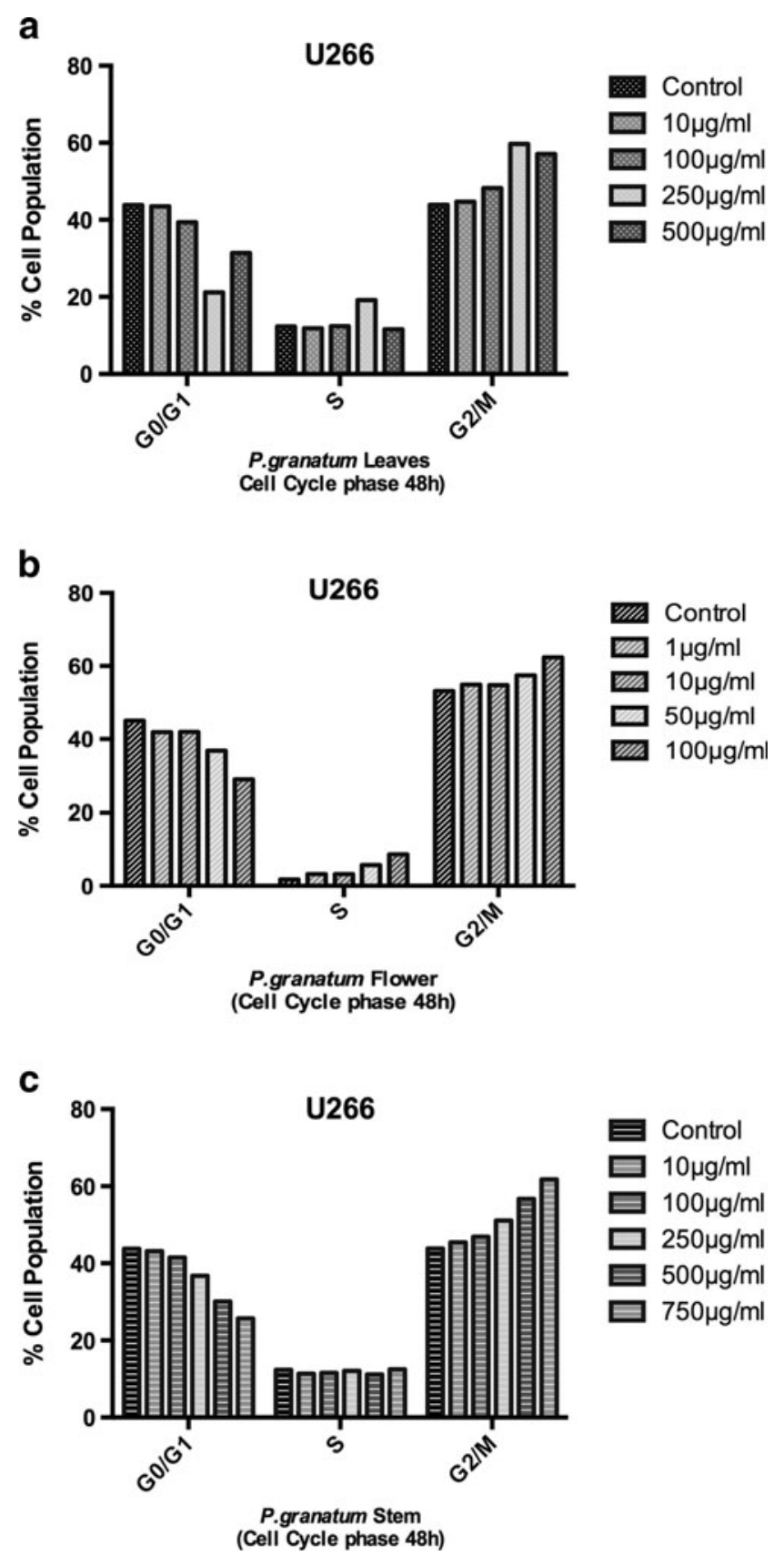

Fig 4 Effects of $P$. granatum extracts on cell cycle progression of U266 cells. Percentage of U266 cell population in different cell cycle phases in response to $P$. granatum leaves (a), flower (b) and stem (c). Flow cytometry results are shown in $\mathbf{d}, \mathbf{e}$ and $\mathbf{f}$, respectively 
d
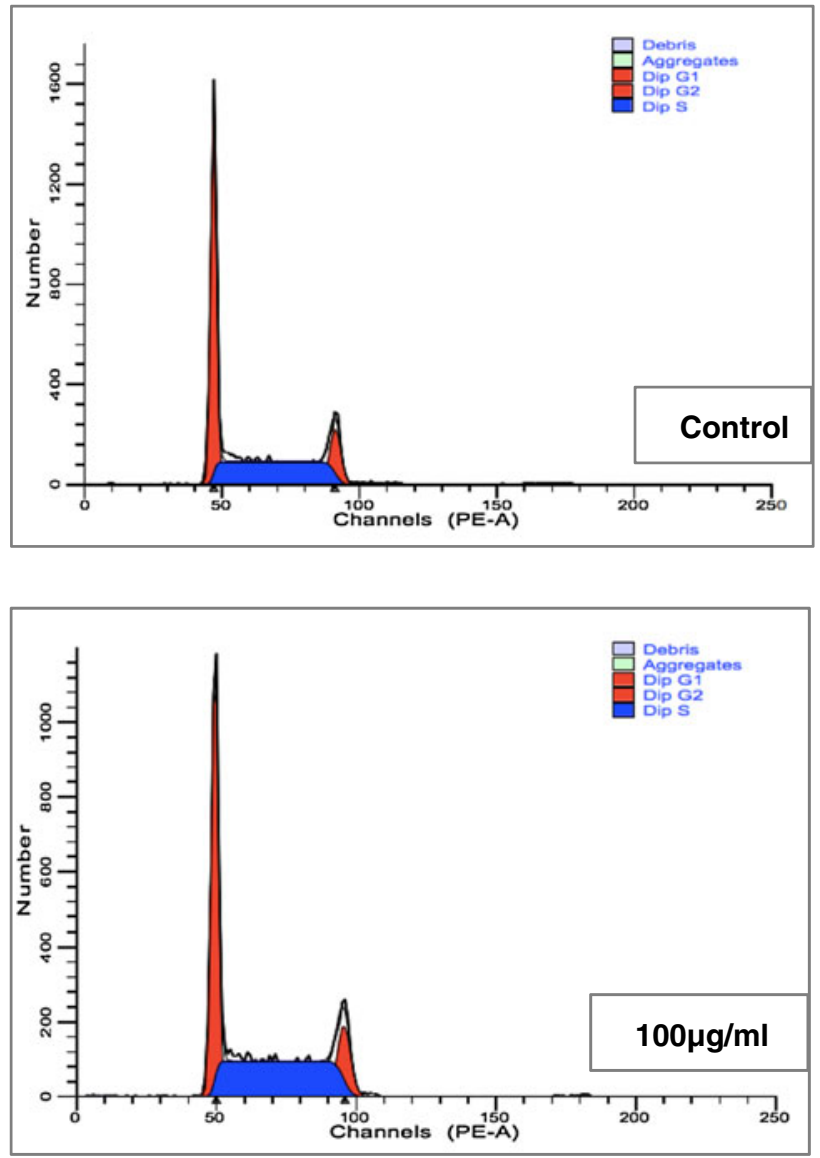
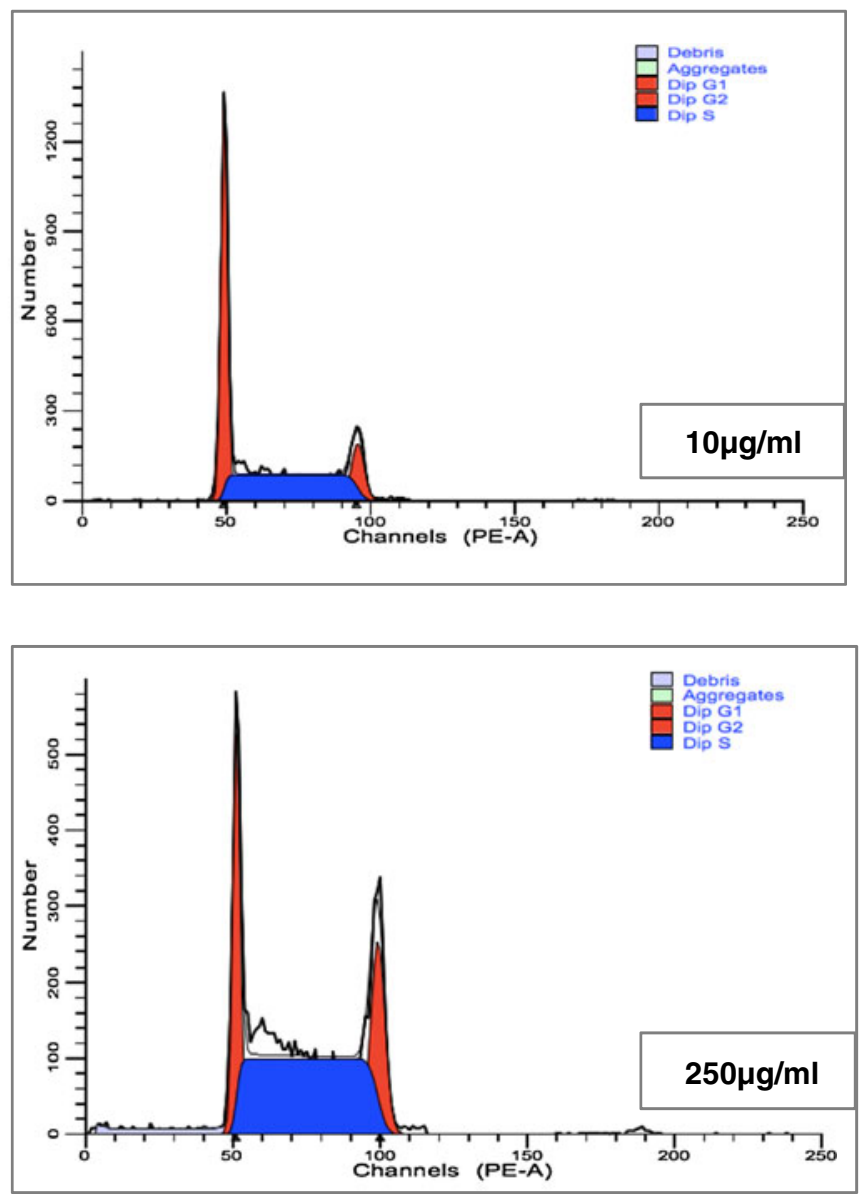

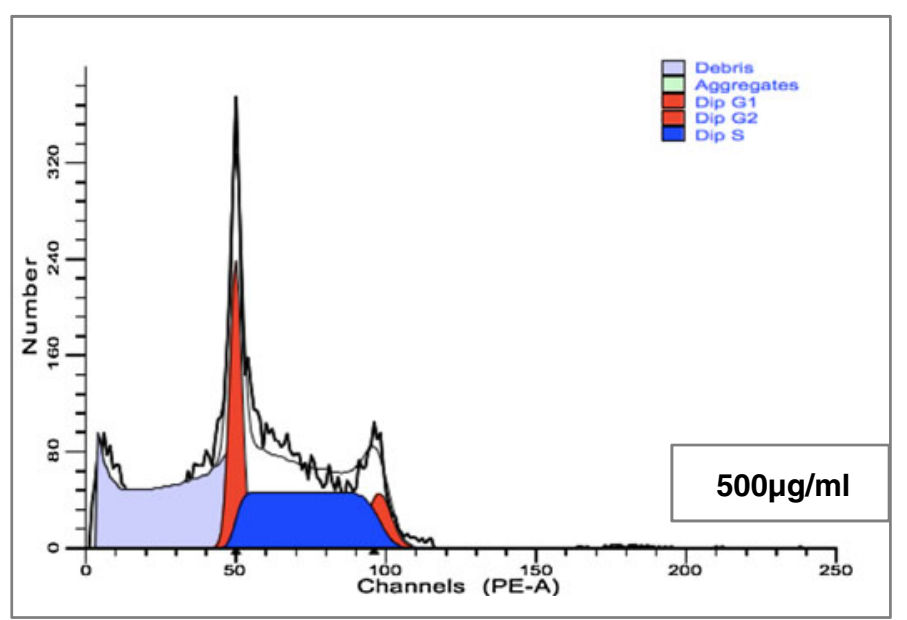

Fig. 4 (continued)

multiple myeloma have limited success and are associated with consequent adverse drug reactions. Although novel agents improve the life quality and survival of patients, most patients will eventually relapse or become refractory to the treatment, making this hematological malignancy incurable [27]. Therefore, the need to identify alternative therapeutic approaches is mandatory. This has led to the search of novel bioactive compounds and/or extracts against multiple myeloma from untapped resources. A plethora of successful anticancer drugs have been derived from natural plant products [28], and the search for new anticancer drugs from the plant kingdom is ongoing. In the same vein, we investigated the cytotoxic and apoptotic effect of non-edible parts of the Mauritian cultivar of pomegranate on U266 multiple myeloma cells. 
e
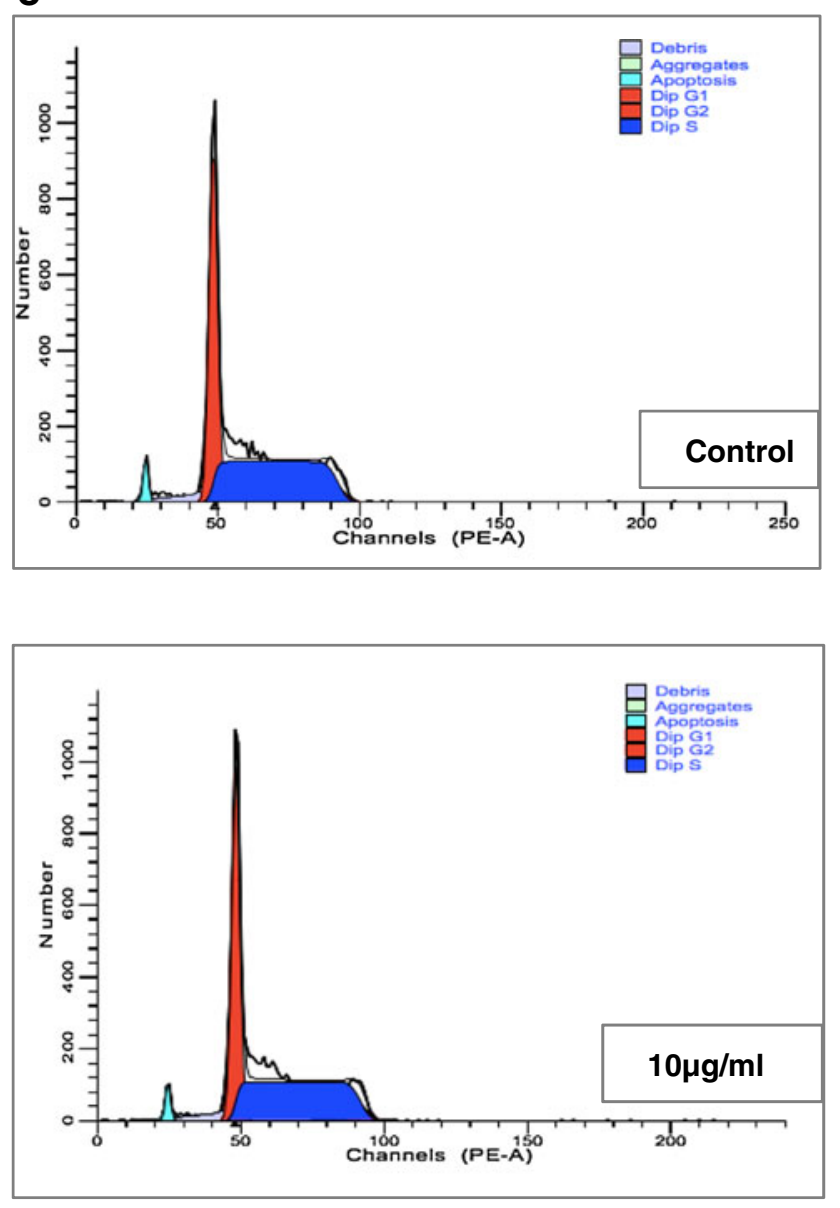
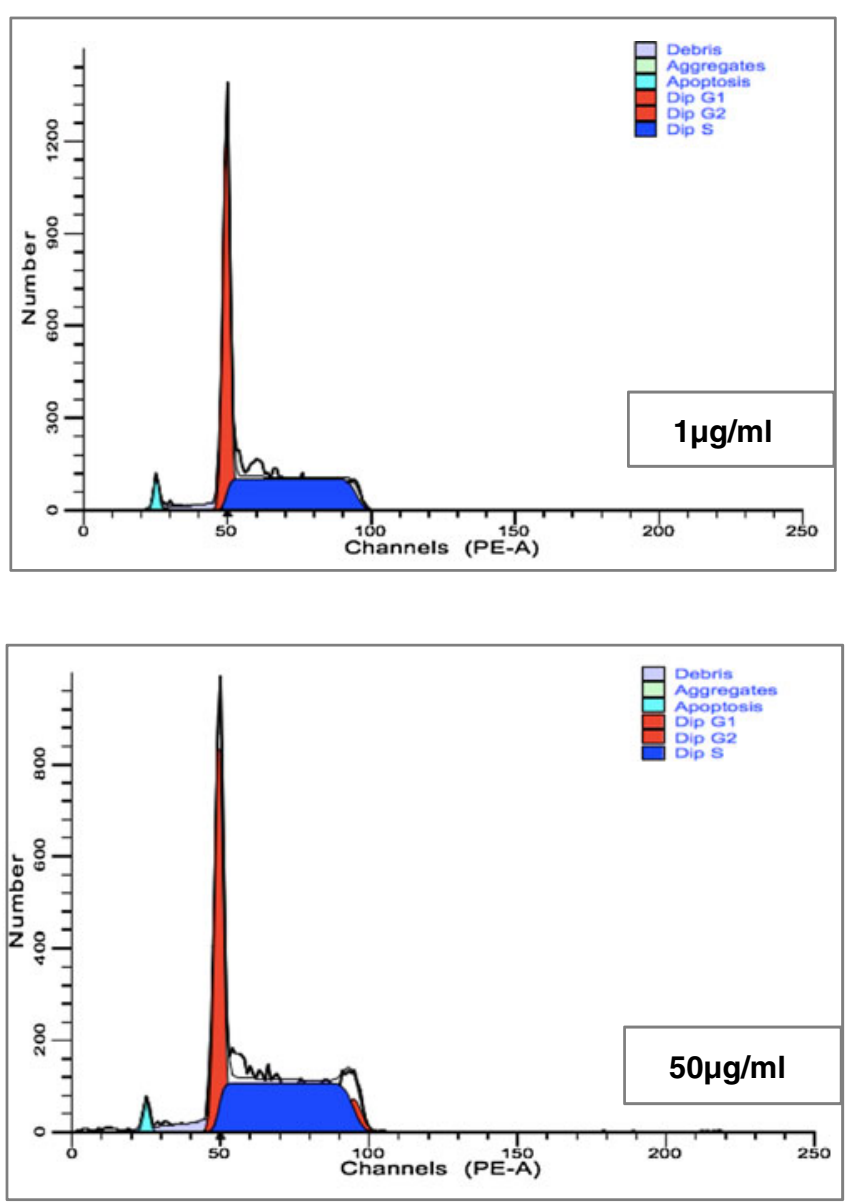

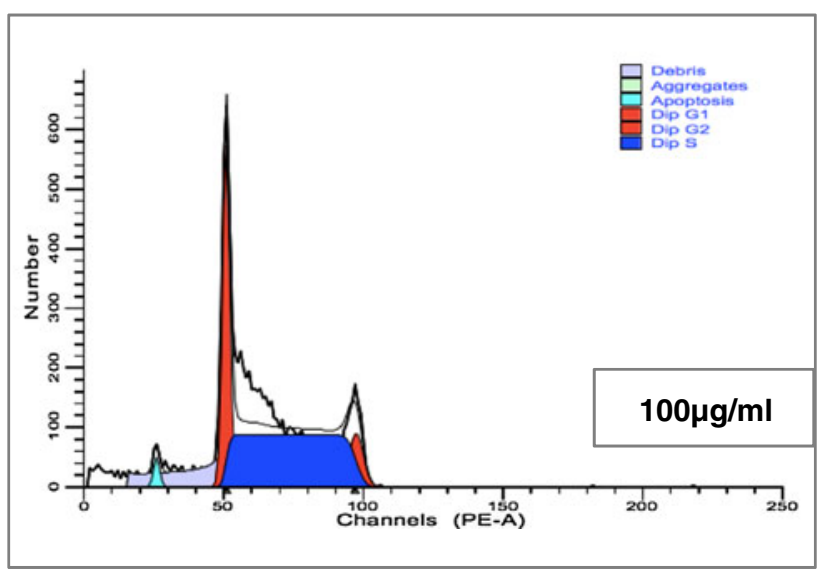

Fig. 4 (continued)

The MTT proliferation assay revealed that all the nonedible part extracts of pomegranate tested reduced the survival of cancerous cells in a dose-dependent manner (Fig. 1a, b). $P$. granatum flower extract showed promising antiproliferative activity against U266 cells compared to the leaves and stem extracts. P. granatum leaves extract at the same concentration tested was however more potent than
P. granatum stem extracts $(p<0.05)$. Furthermore, the flower extract also inhibited cancerous cell proliferation in a timedependent manner, with a calculated $\mathrm{IC}_{50}$ value of 41 and $25 \mu \mathrm{g} / \mathrm{ml}$ for 48 and $72 \mathrm{~h}$ of exposure, respectively. The data highlighted the cytotoxic effect of $P$. granatum leaves, flowers and stem against U266 cells. Similarly, Bekir et al. have reported promising cytotoxic activity of pomegranate leaves 

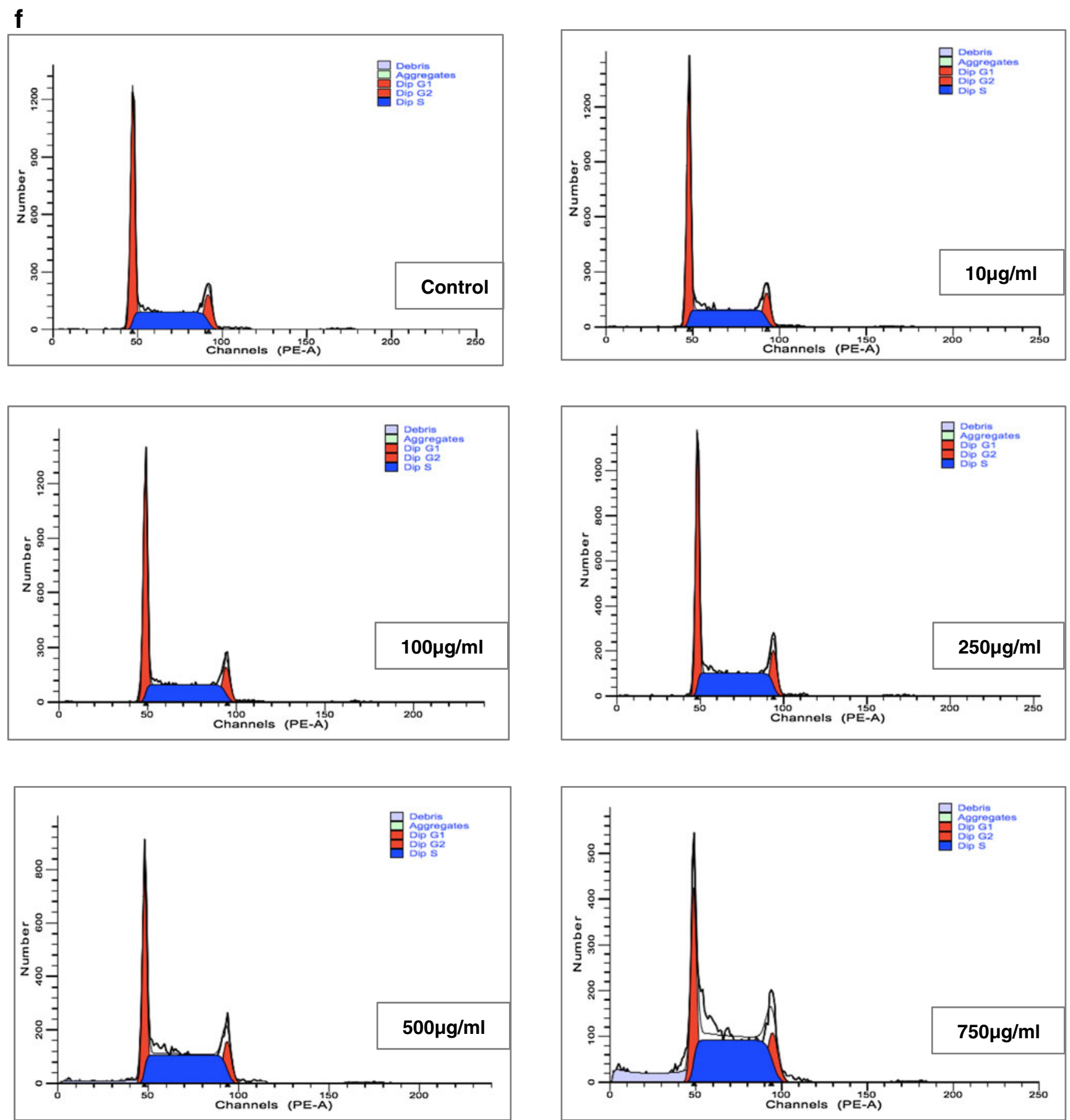

Fig. 4 (continued)

extracts against breast cancer cell line MCF-7, with $\mathrm{IC}_{50}$ values less than $50 \mathrm{mg} / 1$ [29].

Lucci et al. has shown the potent antiproliferative activity of pomegranate seed extract against hormone-dependent human breast cancer $\mathrm{LNCaP}$, with an $\mathrm{IC}_{50}$ value reported to be three times lower than vinblastine. In the same study, they also reported the promising antiproliferative activity of pomegranate seed extract against renal adenocarcinoma $\mathrm{ACHN}\left(\mathrm{IC}_{50}\right.$ value of
$26.5 \mu \mathrm{g} / \mathrm{ml}$ ), human malignant melanoma A375 ( $\mathrm{IC}_{50}$ value of $22.9 \mu \mathrm{g} / \mathrm{ml})$, human amelanotic melanoma $\mathrm{C}_{2} 2\left(\mathrm{IC}_{50}\right.$ value of $15.3 \mu \mathrm{g} / \mathrm{ml}$ ), human breast cancer MCF-7 ( IC $_{50}$ value of $9.6 \mu \mathrm{g} / \mathrm{ml}$ ) and Caucasian lung large cell carcinoma COR-L23 $\left(\mathrm{IC}_{50}\right.$ value of $23 \mu \mathrm{g} / \mathrm{ml}$ ) [30]. Likewise, Orgil et al. compared the antiproliferative activity of both edible and non-edible pomegranate fruit parts against two cancer cell lines (MCF-7 and $\mathrm{LNCaP}$ ) and reported the non-edible sections of the fruit to exert 
highest anti-proliferative activities. The authors further reported that the bark, fruitless and roots exhibited the highest antiproliferative activities. The leaf extract had relatively lower anti-proliferative activity compared to other plant organs and about 4.5-fold lower than the root extracts [31]. This study would be considered as a basis for further investigation to deepen our study by determining the anticancer effects of bark, fruitless and root extracts of $P$. granatum on multiple myeloma cells.

The potent anti-proliferative activities of the non-edible pomegranate extracts have been attributed to the high amount of phenolics present in the extracts [30,31]. Literature abounds in examples of the anti-proliferative and anticancer effect of pomegranate fruit and juice, all of which have been attributed to the high level of phenolic compounds present $[13,16,20,23,32-38]$. Among the different mechanisms of action involved, plant phenolics exert chemopreventive activity via its antioxidative potential [7].

A previous study has reported that the non-edible pomegranate extracts investigated in the present study are very rich sources of polyphenolic and also has potent antioxidant activities [23]. The extracts were obtained by maceration with $70 \%$ methanol which allowed the extraction of polyphenolic compounds. The polyphenolic contents were highest in flower extract with the total phenolic content estimated at $336.51 \pm$ $0.70 \mathrm{mg}$ gallic acid equivalent per gram air dried weight and total flavonoid content to $213.54 \pm 3.14 \mathrm{mg}$ gallic acid equivalent per gram air dried weight. These phytochemicals may contribute to the potent anti-proliferative activity against U266 cells, of the flower extract demonstrated in this study.

Induction of apoptosis by plant phytochemicals has been proposed as a target for cancer prevention [7, 39]. In order to assess the effects of concentration and exposure time of the extracts on apoptosis of multiple myeloma cells, the degree of apoptotic cells was measured by flow cytometry using Annexin-V/PI double stain. It was found that pomegranate flower, leaf and stem extracts were able to increasingly induce apoptosis of the cancerous cells in both concentration- and time-dependent manner (Fig. 2a, d). When U266 cells were treated with leaves extract at concentrations of 500 and $1000 \mu \mathrm{g} / \mathrm{ml}$ for $48 \mathrm{~h}$, eightfold and 15-fold increases in apoptotic cell population were achieved, respectively. For the same tested dose, an exposure time of $72 \mathrm{~h}$ resulted in 13and 19-fold increases, respectively.

MMP is a marker of mitochondrial membrane permeability, and MMP decrease could result in the activation of mitochondrial pro-apoptotic factors [40]. To determine whether multiple myeloma cell apoptosis induced by pomegranate extracts was associated with mitochondrial membrane dysfunction, the loss of MMP was determined using JC-1 probe. All the tested extracts decreased the MMP in U266 cells in a dose-dependent manner (Fig. 3a-c). Pomegranate leaves extracts caused the most significant loss of MMP potential. The extracts under study may induce apoptosis in U266 cells partly by causing loss of MMP.
However, the flower extract showed only $<5 \%$ increase in the loss of the MMP, thereby indicating that the cytotoxic effect on the U266 cells may be ascribed to different mechanisms.

Cell cycle analysis indicated that exposure of U266 cells to the pomegranate extracts resulted in cell cycle arrest at $\mathrm{G} 2 / \mathrm{M}$ phase. However, the flower extract induced an arrest at both $\mathrm{G} 2 / \mathrm{M}$ and $\mathrm{S}$ phase in a dose-dependent manner. The checkpoints that control $\mathrm{G}_{1} / \mathrm{S}$ and $\mathrm{G}_{2} / \mathrm{M}$ transitions act as an inspection mechanism for the persistence of the cell cycle [41]. Thus, when an improper action is detected at the cell cycle checkpoints, such as uncompleted DNA replication or a mismatch that cannot be repaired by the cell, apoptotic cascade would be activated that eventually leads to the death of the cell, representing one of the ideal strategies for cancer therapy [42]. Interestingly, we found that $\mathrm{G}_{2} / \mathrm{M}$ phase arrest of the U266 cells was observed at the highest stem concentration followed by $250 \mu \mathrm{g} / \mathrm{ml}$ leaves extracts (Fig. 4a-f). Nevertheless, the molecular mechanisms of pomegranate extract-induced cell cycle arrest in these cells require further investigation.

\section{Conclusion}

Treatment of U266 cells with the non-edible pomegranate extracts significantly reduced cell proliferation/viability and induced cell death in a dose-dependent manner compared with that in the untreated control. The induced growth inhibition appeared to be associated with triggering of apoptosis particularly for the cells treated with the leaves and stem extracts. In summary, our data demonstrate that the pomegranate leaves, stem and flower extracts modulate cell cycle progression and induce apoptosis in human multiple myeloma cancer cells through G2/M and $\mathrm{S}$ phase cell cycle arrest and mitochondrial membrane permeabilization. These observations suggest an anticancer activity of these extracts and prompt for further investigation into the application of the latter in functional health and cancer chemoprevention.

\section{References}

1. Long JS, Ryan KM. New frontiers in promoting tumour cell death: targeting apoptosis, necroptosis and autophagy. Oncogene. 2012;31:5045-60.

2. Hanahan D, Weinberg RA. The hallmarks of cancer. Cell. 2000;100:7-70.

3. Hanahan D, Weinberg RA. Hallmarks of cancer: the next generation. Cell. 2011;144:646-74.

4. Bode AM, Dong Z. Targeting signal transduction pathways by chemopreventive agents. Mutat Res. 2004;555:33-51.

5. Chun KS, Surh YJ. Signal transduction pathways regulating cyclooxygenase-2 expression: potential molecular targets for chemoprevention. Biochem Pharmacol. 2004;68:1089-100. 
6. Kundu JK, Surh YJ. Breaking the relay in deregulated cellular signal transduction as a rationale for chemoprevention with antiinflammatory phytochemicals. Mutat Res. 2005;591:123-46.

7. Neergheen VS, Bahorun T, Taylor EW, Jen LS, Aruoma OI. Targeting specific cell signaling transduction pathways by dietary and medicinal phytochemicals in cancer chemoprevention. Toxicology. 2010;278:229-41.

8. Jurenka JS. Therapeutic applications of pomegranate (Punica granatum L.): a review. Altern Med Rev. 2008;13:128-44.

9. Ana F, Calhau C. The bioactivity of pomegranate: impact on health and disease. Crit Rev Food Sci Nutr. 2011;51:626-34.

10. Guy R, Guého J. Les Plantes et Leur Histoire À l'Ile Maurice. Mauritius: S.n. 1999.

11. Vera-Ku M, Martha MG, Rosa MP, Miguel RV, Paulino SP, Roberto $\mathrm{CR}$, et al. Medicinal potions used against infectious bowel diseases in Mayan traditional medicine. J Ethnopharmacol. 2010;132:3038 .

12. Tetali P, Waghchaure C, Daswani PG, Antia NH, Birdi TJ. Ethnobotanical survey of antidiarrhoeal plants of Parinche Valley, Pune District, Maharashtra, India. J Ethnopharmacol. 2009;123: 229-36.

13. Adams LS, Zhang Y, Seeram NP, Heber D, Chen S. Pomegranate ellagitannin-derived compounds exhibit antiproliferative and antiaromatase activity in breast cancer cells in vitro. Cancer Prev Res (Phila). 2010;3:108-13.

14. Haidari M, Ali M, Ward Casscells S, Madjid M. Pomegranate (Punica granatum) purified polyphenol extract inhibits influenza virus and has a synergistic effect with oseltamivir. Phytomedicine. 2009;16:1127-36.

15. Endo EH, Cortez DA, Ueda-Nakamura T, Nakamura CV, Dias Filho BP. Potent antifungal activity of extracts and pure compound isolated from pomegranate peels and synergism with fluconazole against Candida albicans. Res Microbiol. 2010;161:534-40.

16. Dahlawi H, Jordan-Mahy N, Clench M, McDougall GJ, Maitre CL. Polyphenols are responsible for the proapoptotic properties of pomegranate juice on leukemia cell lines. Food Sci Nutr. 2013;1: 196-208.

17. Zhang L, Quanjuan Fu Q, Zhang Y. Composition of anthocyanins in pomegranate flowers and their antioxidant activity. Food Chem. 2011;127:1444-49.

18. Lansky EP, Newman RA. Punica granatum (pomegranate) and its potential for prevention and treatment of inflammation and cancer. $\mathrm{J}$ Ethnopharmacol. 2007;109:177-206.

19. Jeune MA, Kumi-Diaka J, Brown J. Anticancer activities of pomegranate extracts and genistein in human breast cancer cells. J Med Food. 2005;8:469-75.

20. Pantuck AJ, Leppert JT, Zomorodian N, Aronson W, Hong J, Barnard RJ, et al. Phase II study of pomegranate juice for men with rising prostate-specific antigen following surgery or radiation for prostate cancer. Clin Cancer Res. 2006;12:4018-26.

21. Paller CJ, Ye X, Wozniak PJ, Gillespie BK, Sieber PR, Greengold $\mathrm{RH}$, et al. A randomized phase II study of pomegranate extract for men with rising PSA following initial therapy for localized prostate cancer. Prostate Cancer P D. 2013;16:50-5.

22. Ampasavate C, Okonogi S, Anuchapreeda S. Cytotoxicity of extracts from fruit plants against leukemic cell lines. Afr J Pharm Pharmacol. 2010;4:13-21.

23. Dahlawi H, Jordan-Mahy N, Clench M, Le Maitre CL. Bioactive actions of pomegranate fruit extracts on leukemia cell lines in vitro hold promise for new therapeutic agents for leukemia. Nutr Cancer. 2012;64:100-10

24. Rummun N, Somanah J, Ramsaha S, Bahorun T, NeergheenBhujun VS. Bioactivity of nonedible parts of Punica granatum
L.: a potential source of functional ingredients. Int $\mathrm{J}$ Food Sci. 2013;1-12.

25. Baran Y, Bielawski J, Gunduz U, Ogretmen B. Targeting glucosylceramide synthase sensitizes imatinib-resistant chronic myeloid leukemia cells via endogenous ceramide accumulation. J Cancer Res Clin Oncol. 2011;137:1535-44.

26. Gencer EB, Ural AU, Avcu F, Baran Y. A novel mechanism of dasatinib-induced apoptosis in chronic myeloid leukemia; ceramide synthase and ceramide clearance genes. Ann Hematol. 2011;90: 1265-75.

27. De la Puente P, Muz B, Azab F, Luderer M, Azab AK. Molecularly targeted therapies in multiple myeloma. Leuk Res Treat. 2014;2014:1-8.

28. Kinghorn AD, Farnsworth NR, Soejarto DD, Cordell GA, Pezzuto JM, Udeani GO, et al. Novel strategies for the discovery of plantderived anticancer agents. Pure Appl Chem. 1999;71:1611-18.

29. Bekir J, Mars M, Souchard JP, Bouajila J. Assessment of antioxidant, anti-inflammatory, anti-cholinesterase and cytotoxic activities of pomegranate (Punica granatum) leaves. Food Chem Toxicol. 2013;55:470-5.

30. Lucci P, Pacetti D, Loizzo MR, Frega NG. Punica granatum cv. Dente Di Cavallo seed ethanolic extract: antioxidant and antiproliferative activities. Food Chem. 2015;167:475-83.

31. Orgil O, Schwartz E, Baurch L, Matityahu I, Mahajna J, Amir R. The antioxidative and anti-proliferative potential of non-edible organs of the pomegranate fruit and tree. LWT-Food Sci Technol. 2014;58:571-7.

32. Aqil F, Munagala R, Vadhanam MV, Kausar H, Jeyablan J, Schultz DJ, et al. Anti-proliferative activity and protection against oxidative DNA damage by punicalagin isolated from pomegranate husk. Food Res Int. 2012;49:345-53.

33. Bishayee A, Thoppil RJ, Darvesh AS, Ohanyan V, Meszaros JG. Pomegranate phytoconstituents blunt the inflammatory cascade in a chemically induced rodent model of hepatocellular carcinogenesis. J Nutr Biochem. 2013;24:178-87.

34. Hong MY, Seeram NP, Heber D. Pomegranate polyphenols downregulate expression of androgen-synthesizing genes in human prostate cancer cells overexpressing the androgen receptor. J Nutr Biochem. 2008; 19:848-55.

35. Koyama S, Cobb LJ, Mehta HH, Seeram NP, Heber D, Pantuck AJ, et al. Pomegranate extract induces apoptosis in human prostate cancer cells by modulation of the IGF-IGFBP axis. Growth Hormon IGF Res. 2010;20:55-62.

36. Ming DS, Pham S, Deb S, Chin MY, Kharmate G, Adomat H, et al. Pomegranate extracts impact the androgen biosynthesis pathways in prostate cancer models in vitro and in vivo. J Steroid Biochem Mol Biol. 2014;143:19-28.

37. Sreeja S, Santhosh Kumar TR, Lakshmi BS, Sreeja S. Pomegranate extract demonstrate a selective estrogen receptor modulator profile in human tumor cell lines and in vivo models of estrogen deprivation. J Nutr Biochem. 2012;23:725-32.

38. Wang L, Ho J, Glackin C, Martins-Green M. Specific pomegranate juice components as potential inhibitors of prostate cancer metastasis. Transl Oncol. 2012;5:344-55.

39. Shahneh FZ, Baradaran B, Orangi M, Zamani F. In vitro cytotoxic and apoptotic activity of four Persian medicine plants on human leukemia and lymphoma cells. Asian Pac J Trop Dis. 2014;4:415-20.

40. $\mathrm{Hu} \mathrm{W}$, Kavanagh JJ. Anticancer therapy targeting the apoptotic pathway. Lancet Oncol. 2003;4:721-9.

41. Kastan MB, Bartek J. Cell-cycle checkpoints and cancer. Nature. 2004;432:316-23.

42. Schwartz GK, Shah M. Targeting the cell cycle: a new approach to cancer therapy. J Clin Oncol. 2005;23:9408-21. 